\title{
PATTERN OF MOBILE PHONE USE AND ITS EFFECT AMONG MEDICAL STUDENTS
}

\author{
Anju Gahlot ${ }^{1}$, Pooja Chaudhary22, Satyendra Kumar Gahlot ${ }^{3}$ \\ 1 Professor, Department of Community Medicine, Rama Medical College. \\ ${ }^{2}$ Assistant Professor, Department of Community Medicine, Rama Medical College. \\ ${ }_{3}^{3}$ Associate Professor, Department of Anaesthesia, Rama Medical College.
}

\begin{tabular}{l}
\hline ABSTRACT \\
\hline BACKGROUND \\
Mobile phone use has been tremendously increased in the last decades. Although mobile phone is used by large section of \\
society, but awareness about its adverse effects has not increased in the same proportion. Hence, the present study was taken up to \\
focus the pattern and effect of mobile phone usage amongst medical students.
\end{tabular}

AIM

To study the pattern of use of mobile phone and its effects.

\section{STUDY DESIGN}

A cross-sectional study was carried out at Rama Medical College and Research Centre, Kanpur, amongst 169 medical students by using a predesigned and pretested questionnaire.

\section{RESULTS}

Out of 169 study subjects, $94 \%$ were using smart phone; $52 \%$ of participants were spending 200-500 Rs. monthly for mobile recharge and $72 \%$ of the subjects had been using the cell phone for less than $2 \mathrm{hrs}$. a day. Music and internet $40 \%$ were the most frequently used application by the participants; $60 \%$ of respondents agreed that mobile use hampers their study and $90 \%$ were admitted that mobile use can cause road accidents. Maximum $68 \%$ subjects were not aware regarding protection against the mobile hazards; $25 \%$ of 169 students stated that cell usage causes headache.

\section{CONCLUSION}

Present study found that most of the students were using smart phone. Internet and music were the favourite features amongst them. Most of them know that mobile use hampers studies and causes road accidents, but in spite of that very few of them were aware of the protective measures.

\section{KEYWORDS}

Mobile Phone, Students, Side Effects.

HOW TO CITE THIS ARTICLE: Gahlot A, Chaudhary P, Gahlot SK. Pattern of mobile phone use and its effect among medical students. J. Evolution Med. Dent. Sci. 2016;5(41):2524-2527, DOI: 10.14260/jemds/2016/589

\section{INTRODUCTION}

Mobile phones have become an indispensable part of our lives. They keep you connected with routines, emergency, friends and business. Hardly anyone can think of staying without a mobile for a few minutes.

Cell phones are important means of connectivity amongst all section of society irrespective of rich or poor. In past decades, mobile were used as luxury item, but in recent years it has become a routine necessity. Although mobiles have multifaceted benefits, but the long-term use has adverse effects which have not yet drawn attention to the masses.

In the last 20 years world wide mobile phone subscriptions have grown from 12.4 million to over 5.6 billion, penetrating about $70 \%$ of global population.(1) In spite of some knowledge on unfavourable health effects, the usage of cell phone has increased dramatically, especially since the time they have become more affordable and available all over the world.(2)

Financial or Other, Competing Interest: None.

Submission 16-01-2016, Peer Review 29-04-2016,

Acceptance 07-05-2016, Published 21-05-2016.

Corresponding Author:

Dr. Anju Gahlot,

Add: M/84 Kakadeo, Kanpur.

E-mail:dranjugahlot@gmail.com

DOI: $10.14260 /$ jemds $/ 2016 / 589$
In India too, we note that the scenario is similar with people from both rural and urban areas, educated or illiterate and belonging to all age groups; now dependent on cellular phone. The alarming fact is that many of these devices reach the market without any safety testing on their electromagnetic radiation.(3) There has been controversy about the hazards related to cell phone use, which have been reported to include headache, sleep disturbance, lack of concentration, impairment of short term memory, dizziness, heating of the ear, burning skin, brain tumours and hypertension.(4)

Parents providing small children with cell phones may be under the mistaken assumption of keeping the check on them, but it may prove to be more harmful than good. Mobile phone growth in India has been fast and it has reached all segments of society, especially the young.(5)

Medical college students might be more vulnerable because of the heavy use of smart phone for study and work. (6)

This term was basically introduced in the market for a new class of mobile phones that provides integrated services from communication, computing and mobile sectors such as voice communication, messaging, personal information management applications and wireless communication capability.(7) 
Hence, the present study conducted among medical students to observe the pattern of mobile use and its adverse effects.

\section{MATERIAL AND METHOD}

The present study was a cross sectional study conducted among 169 MBBS students in Rama Medical College during June 2015 to Sep. 2015. At the time of study, 4 batches were available in which 2 were selected randomly for the study. A written consent from Ethical Committee was taken pre-hand. Each batch had strength of 100 students. They were approached after the lecture for participation in the study. Amongst 200 students, 169 were available and 31 were absent.

Participants were first explained about the rationale of study and verbal informed consent was obtained. The data was collected by using a pre-designed, pretested, semistructured questionnaire which included information regarding socio-demographic data, type of mobile, duration of use, effect of prolonged use, favourite features and protective measures.

Data was entered in MS Excel and analysed by using SPSS version 21. Chi-square test was used to find the significance and $\mathrm{p}$ value $<.05$ was taken as statistically significant.

\section{RESULTS}

The study population comprised $53.25 \%$ male and $46.75 \%$ female students. It was observed that a higher percentage of subjects $53.8 \%$ were below 19 yrs. of age, i.e. between 18-19 yrs. and $20-21$ yrs. of age group includes $42.1 \%$ of the study subjects and $22-23$ yrs. include $4.1 \%$ of subjects. (Findings of general information summarized in Table 1 ).

Out of 169 study subjects, 94\% were using smart phone and $6 \%$ using basic phone; $52 \%$ of participants were spending 200-500 Rs. monthly for mobile recharge; $72 \%$ of the subjects had been using the cell phone for less than $2 \mathrm{hrs}$. a day, while the rest $28 \%$ had been using it for more than 2 hrs. a day. Out of the different feature of the mobile, music and internet $40 \%$ were the most frequently used application by the participants. Main purpose of mobile amongst the medical students were to communicate with friends and family $51 \%$. Switching off the mobile during night hrs. is an important protective measure. Other protective measures are not using the mobile during charging and keeping it away from the head during sleep. Only $2.4 \%$ of the students followed the protective measures. (Information regarding pattern of mobile use is given in Table 2 ).

$60 \%$ of respondents agreed that mobile use hampers their study and $90 \%$ admitted that mobile use can cause road accidents. Maximum $68 \%$ subjects were not aware regarding protective measures against the mobile hazards. Restlessness among participants increased when phone did not work either due to no signal or low battery or they did not have mobile. (Awareness of respondents were summarized in Table 3).

$31 \%$ of the 169 students responded when queried on lack of concentration. They admitted that they were disturbed by frequent call/message from other, which did not allow them to complete their academic activities at one stretch; $25 \%$ of 169 students stated that cell usage caused headache. (Side effects of mobile use are summarized in Table 4). The association between duration of mobile use and number of subjects with complaints is statistically significant. As the calculated chi-square (4.83) is greater than table value of chisquare (3.84) at $5 \%$ level of significance (Table 5).

\begin{tabular}{|c|c|c|c|c|c|c|}
\hline Age Group & \multicolumn{2}{|c|}{ Boys } & \multicolumn{2}{c|}{ Girls } & \multicolumn{2}{c|}{ Total } \\
\hline & No. & \% & No. & \% & No. & $\%$ \\
\hline $18-19$ & 46 & 51.1 & 45 & 57 & 91 & 53.8 \\
\hline $20-21$ & 39 & 43.3 & 32 & 40.5 & 71 & 42.1 \\
\hline $22-23$ & 5 & 5.6 & 2 & 2.5 & 7 & 4.1 \\
\hline Total & $\mathbf{9 0}$ & $\mathbf{1 0 0}$ & $\mathbf{7 9}$ & $\mathbf{1 0 0}$ & $\mathbf{1 6 9}$ & $\mathbf{1 0 0}$ \\
\hline \multicolumn{6}{|c|}{ Table I: Distribution of Subjects } \\
According to Age and Gender \\
\hline
\end{tabular}

\begin{tabular}{|c|c|c|}
\hline Type of Mobile & Frequency & Percent \\
\hline Basic & 10 & 6 \\
\hline Smart Phone & 159 & 94 \\
\hline \multicolumn{3}{|l|}{ Money Spent Monthly } \\
\hline$<200$ & 24 & 14 \\
\hline $200-500$ & 88 & 52 \\
\hline $600-1000$ & 30 & 18 \\
\hline$>1000$ & 27 & 16 \\
\hline \multicolumn{3}{|l|}{ /frqn of use } \\
\hline$<2$ hrs/day & 122 & 72 \\
\hline 2-5 hrs/day & 34 & 20 \\
\hline 5-8 hrs/day & 6 & 4 \\
\hline$>8 \mathrm{hrs} /$ day & 7 & 4 \\
\hline \multicolumn{3}{|l|}{ Favourite Feature } \\
\hline Camera & 13 & 8 \\
\hline Music & 68 & 40 \\
\hline Internet & 68 & 40 \\
\hline Gaming & 13 & 8 \\
\hline Text Messaging & 7 & 4 \\
\hline \multicolumn{3}{|l|}{ Main Purpose of Mobile } \\
\hline Emergency & 22 & 13.02 \\
\hline Friends \& Family & 87 & 51.48 \\
\hline Business & 11 & 6.51 \\
\hline All above & 49 & 28.99 \\
\hline Table II: Patterns of M & se Amongst & lents \\
\hline
\end{tabular}

\begin{tabular}{|l|c|c|}
\hline 1) Do You Know & & \\
\hline a) Mobile use Hampers Studies & Frequency & Percent \\
\hline Yes & 101 & 60 \\
\hline No & 68 & 40 \\
\hline $\begin{array}{c}\text { b) Mobile use Causes Road } \\
\text { Accidents }\end{array}$ & & \\
\hline Yes & 152 & 90 \\
\hline No & 17 & 10 \\
\hline c) Protection Against the Hazards & Frequency & Percent \\
\hline Yes & 54 & 32 \\
\hline No & 115 & 68 \\
\hline $\begin{array}{l}\text { 2) Restlessness among Students } \\
\text { when there is no Signal, Low } \\
\text { Battery \& Restricted use of Mobile } \\
\text { Yes }\end{array}$ & & \\
No & 99 & 58.88 \\
No Signal & 70 & 41.42 \\
Yes & 119 & 70.41 \\
No & 50 & 29.59 \\
\hline
\end{tabular}




\begin{tabular}{|c|c|c|}
\hline Low Battery & 99 & 58.58 \\
Yes & 70 & 41.42 \\
No & & \\
No Mobile & 97 & 57.40 \\
Yes & 72 & 42.60 \\
No & \\
\hline \multicolumn{2}{|c|}{ Table III: Awareness Among Students } \\
\hline
\end{tabular}

\begin{tabular}{|c|c|c|}
\hline $\begin{array}{c}\text { Side Effects of } \\
\text { Mobile Use }\end{array}$ & Frequency & Percent \\
\hline Headache & 43 & 25.3 \\
\hline Irritation & 31 & 18.4 \\
\hline $\begin{array}{c}\text { Lack of } \\
\text { Concentration } \\
\text { in Work }\end{array}$ & 53 & 31.7 \\
\hline $\begin{array}{c}\text { Sleep } \\
\text { Disturbance }\end{array}$ & 42 & 24.6 \\
\hline Total & 169 & 100 \\
\hline $\begin{array}{r}\text { Tabl } \\
\text { Mobi }\end{array}$ & $\begin{array}{l}\text { Prevalence } \\
\text { e Amongst } \mathrm{M}\end{array}$ & $\begin{array}{l}\text { ts of } \\
\text { ents }\end{array}$ \\
\hline
\end{tabular}

\begin{tabular}{|c|c|c|}
\hline Duration of Use & Complaint & No. of Complaint \\
\hline$<5$ yrs. & 14 & 7 \\
\hline$>5$ yrs. & 61 & 87 \\
\hline
\end{tabular}

This result is significant at $\mathrm{p}<0.05$.

Chi-square, the statistic is 4.83 .

\section{DISCUSSION}

As evident from the above mentioned result, majority 53.8\% of subjects were below 20 yrs. of age. This is comparable with the study done by Macro in Mumbai.(8)

$94 \%$ of study subjects possess smart phone and $6 \%$ had a basic phone. While Jamal et al( ${ }^{(9)}$ report that $53.2 \%$ were using smart phone. This difference could be due to the fact that the study was carried out in a private medical college.

The average amount of money, which was spent on monthly recharge was 200-500 Rs. in 52\% students and the results were comparable with Sonu H. Subha et al.(10) Frequency of mobile use per day was $<2 \mathrm{hrs}$., found in $72 \%$ of subjects. This was similar to the finding reported by Acharya JP.(11), Sonu H. Subha et al and Zulkefly and Baaharrddin.(12)

Out of all the features, music and internet were the favourite features among medical students (40\%) followed by camera and gaming ( $8 \%)$ and text messaging $(9 \%)$, but suitable literature on favourite features of mobile could not be traced and more research required to correlate with this fact. Main purpose of mobile among medical students was to keep in touch with friends and family (51.48\%) and this finding was similar to the study of Sonu H. Subha et al and the study which was done on Malaysian college student, which reported $51 \%$ of students talked to their parents most often.

When students were asked about their knowledge, 60\% of participants admitted the fact that mobile hampers their study and $90 \%$ of subjects responded that mobile can causeroad accidents. Although every student was using mobile phones, but yet only $32 \%$ were aware of the protective measures against mobile hazards. Only $2.4 \%$ of students were aware of the importance of switching off mobile. More research is needed to corroborate this fact.

Among all the students (58.88\%) became restless when there were no signal, low battery or restricted use of mobile (As mobile is not allowed during college hrs.). Similarly, Brijendra et al(13) revealed that $53 \%$ of the subjects tend to be anxious when they lose their mobile, run out of battery or have no network coverage and Acharya JP et al revealed that restlessness does result amongst those who use their phone excessively; $33 \%$ of participants in Jamal et al did not feel safe in absence of mobile. Sonu $\mathrm{H}$ Subha et al showed that respondents got anxietic when they stop using mobile phones and become very or extremely upset if there were network inaccessibility.

Though mobile are easy means of accessibility and connectivity, they make people's lives and work more easy, they adversely affect the health of individuals who are not very much aware.

$25 \%$ of study subjects experience headache as a side effect of mobile. Similar findings were given by Jamal et al, Maier et al, Acharya JP and Pendse Nilesh et al.(14) Among all the subjects, $31 \%$ showed lack of concentration in work. Similar response given by Jamal et al, Maier et al, Pendse Nilesh \& Brijender et al.

$24.6 \%$ of respondents revealed sleep disturbance as side effect of mobile and similar findings presented by Jamal et al, Acharya JP and Maier et al as well.

\section{CONCLUSION}

This study found that most of the students were using smart phones and they spent 200-500 monthly and mainly they used mobile phones for $<2 \mathrm{hrs}$./day. Internet and music were the favourite features amongst them. Most of the time they talk to the family members and friends. Most of them know that mobile use hampers studies and cause road accidents, but in spite of that very few of them were aware of the protective measures.

Restricted use of mobile, low battery and no signal leads to restlessness amongst maximum of the students.

Lack of concentration, sleep disturbance and headache were the common side effects experienced by participants.

\section{LIMITATIONS}

1. As the study was applied only on a small group of students, so results may not reflect the scenario worldwide.

2. Health effects were self-reported.

\section{RECOMMENDATIONS}

1. There is need to further explore the extent and the effect of mobile usage in various groups to plan intervention measures.

2. Mobile use during college hours should be strictly prohibited.

3. Mobile awareness and safety measures should be included as a part of curriculum from the very beginning, so that students can be shielded from the hazards and can improve their academic performance of $5 \mathrm{yrs}$.

\section{REFERENCES}

1. Electromagnetic fields and public health: mobile phones. WHO: fact sheet no 193, 2011. 
2. Cell phone. Centre on media and child health, children hospital, Boston 2007.

3. Kovach $\mathrm{S}$. The hidden danger of cell phone radiation. Life extension 2007.

4. Maier M, Blakemore C, Kovisto M. The health hazards of mobile phone. Br Med Of 2000;320(7245):1288-9.

5. Report of the committees on India-vision 2020 planning commissions' government of India. New Delhi dec 2002.

6. Al-khlaiwi $\mathrm{T}$, Meo SA. Association of mobile phone radiation with fatigue, headache, dizziness, tension \& sleep disturbance in Saudi population. Saudi med journal 2004;25(6):732-6.

7. Sarwar M, Soomro TR. Impact of smartphone's on society. Eur J Sci Res 2013;98(2):216-26.

8. Macro market analysis and consumer research organization. A report on study of mobile phone usage among the teenagers and youth in Mumbai, April-May 2004.

9. Arwa Jamal, Rehan Sedie, Khadijah Abdul Haleem, et al. Pattern of use of smart phone among female medical students and self-reported effect. Journal of Taiban University Medical Sciences 2012;7(1):45-9.
10. Sonu H Subba, Chetan Mandelia, Vaibhav Pathak, et al. Ringxiety and the mobile phone usage pattern among the students of a medical college in south India. Journal of clinical and diagnostic research 2013;7(2):205-9.

11. Acharya JP, Achrya I, Waghrey D. A study on some of the common health effect of cell phone amongst college students. J community medicine health education 2013;2(3):388-94.

12. Zulkefly SN, Baaharudin R. Mobile phone use amongst students in a university in Malaysia: its correlates and relationship to psychological health. European Journal of Scientific Research 2009;27(2):206-18.

13. Singh B, Gupta R, Garg R. Mobile phone: a boon or bone for mankind? Behaviour of medical students. Int J of innovative Res \& development 2013;2(4):197-201.

14. Pendse N, Zagade T. Knowledge \& attitude. Regarding health hazards of mobile phone use among the junior college students. International Journal of Science and Research 2014;3(5):554-61. 